\title{
Timing of meltwater pulse 1a and climate responses to meltwater injections
}

\author{
Jennifer D. Stanford, ${ }^{1}$ Eelco J. Rohling, ${ }^{1}$ Sally E. Hunter, ${ }^{1}$ Andrew P. Roberts, ${ }^{1}$ \\ Sune O. Rasmussen, ${ }^{2}$ Edouard Bard, ${ }^{3}$ Jerry McManus, ${ }^{4}$ and Richard G. Fairbanks ${ }^{5}$ \\ Received 5 July 2006; revised 18 August 2006; accepted 13 September 2006; published 9 December 2006.
}

[1] The temporal relationship between meltwater pulse 1a (mwp-1a) and the climate history of the last deglaciation remains a subject of debate. By combining the Greenland Ice Core Project $\delta^{18} \mathrm{O}$ ice core record on the new Greenland ice core chronology 2005 timescale with the U/Th-dated Barbados coral record, we conclusively derive that mwp-1a did not coincide with the sharp Bølling warming but instead with the abrupt cooling of the Older Dryas. To evaluate whether there is a relationship between meltwater injections, North Atlantic Deep Water (NADW) formation, and climate change, we present a high-resolution record of NADW flow intensity from Eirik Drift through the last deglaciation. It indicates only a relatively minor 200-year weakening of NADW flow, coincident with mwp-1a. Our compilation of records also indicates that during Heinrich event 1 and the Younger Dryas there were no discernible sea level rises, and yet these periods were characterized by intense NADW slowdowns/shutdowns. Clearly, deepwater formation and climate are not simply controlled by the magnitude or rate of meltwater addition. Instead, our results emphasize that the location of meltwater pulses may be more important, with NADW formation being particularly sensitive to surface freshening in the Arctic/Nordic Seas.

Citation: Stanford, J. D., E. J. Rohling, S. E. Hunter, A. P. Roberts, S. O. Rasmussen, E. Bard, J. McManus, and R. G. Fairbanks (2006), Timing of meltwater pulse 1a and climate responses to meltwater injections, Paleoceanography, 21, PA4103,

doi:10.1029/2006PA001340.

\section{Introduction}

[2] Well-dated fossil corals [Fairbanks, 1989, 1990; Bard et al., 1990a, 1990b, 1996; Fairbanks et al., 2005], and other methods [e.g., Rohling et al., 1998; Hanebuth et al., 2000; Siddall et al., 2003], have documented that global sea level has risen by $120 \mathrm{~m}$ or more since the Last Glacial Maximum. The combined use of Accelerator Mass Spectrometry (AMS) ${ }^{14} \mathrm{C}$ and U/Th datings in fossil coral studies offers insight into the real time structure of the deglacial sea level rise, and also allows extension of the radiocarbon calibration curve beyond $10 \mathrm{ka}$ (thousands of years before Present, where Present refers to A.D. 1950) [Bard et al., 1990a, 1998; Reimer et al., 2004; Fairbanks et al., 2005]. Fossil coral records contain evidence of a dramatic sea level rise in excess of $20 \mathrm{~m}$ within the last deglaciation, the so-called meltwater pulse (mwp-1a) [Fairbanks, 1989; Fairbanks et al., 2005; Bard et al., 1990b, 1996; Hanebuth et al., 2000;

\footnotetext{
${ }^{1}$ National Oceanography Centre, University of Southampton, Southampton, UK.

${ }^{2}$ Ice and Climate Research, Niels Bohr Institute, University of Copenhagen, Copenhagen, Denmark.

${ }^{3}$ Collège de France, Centre Européen de Recherche et d'Enseignement des Géosciences de l'Environnement, UMR 6635 and Université d'AixMarseille III, Europôle de l'Arbois, Aix-en-Provence, France.

${ }^{4}$ Woods Hole Oceanographic Institution, Woods Hole, Massachusetts, USA.

${ }^{5}$ Lamont-Doherty Earth Observatory and Department of Earth and Environmental Science, Columbia University, Palisades, New York, USA.

Copyright 2006 by the American Geophysical Union. 0883-8305/06/2006PA001340
}

Weaver et al., 2003]. However, controversy remains about the precise age of mwp-1a, with published values varying from around $14.6 \mathrm{ka}$ [Hanebuth et al., 2000] to $14 \mathrm{ka}$ [Bard et al., 1996; Fairbanks et al., 2005].

[3] A marked step in the last deglaciation is recognized in Greenland ice core records by the sharp Bølling warming (GI-1e) [Björck et al., 1998], dated at around $14.6 \mathrm{ka}$ [Rasmussen et al., 2006]. At around $14 \mathrm{ka}$, the Bølling warm period was ended abruptly by the Older Dryas cold event (GI-1d) [Björck et al., 1998; Rasmussen et al., 2006]. On the basis of an inferred age of around $14.6 \mathrm{ka}$ for mwp-1a, this meltwater event has been suggested as a trigger for the Bølling warming [Hanebuth et al., 2000]. Isostatic rebound calculations and ocean-climate modeling results have been used to support the suggestion that mwp-1a was derived from Antarctica and was the direct cause for the Bølling warming [Clark et al., 1996, 2002; Kienast et al., 2003; Weaver et al., 2003]. In contrast, earlier results from the Barbados and Tahiti fossil coral records were used to infer that mwp-1a should instead be associated with the Older Dryas cooling that terminated the Bølling warming [Bard et al., 1996].

[4] To resolve this controversy, we compare the Greenland ice core climate proxy record on the new layercounted Greenland ice core chronology 2005 (GICC05) timescale [Rasmussen et al., 2006], with the latest U/Thdated history of deglacial sea level change [Fairbanks et al., 2005; Peltier and Fairbanks, 2006]. To evaluate the implications of the resolved relative timings between these records with respect to climate change mechanisms asso- 


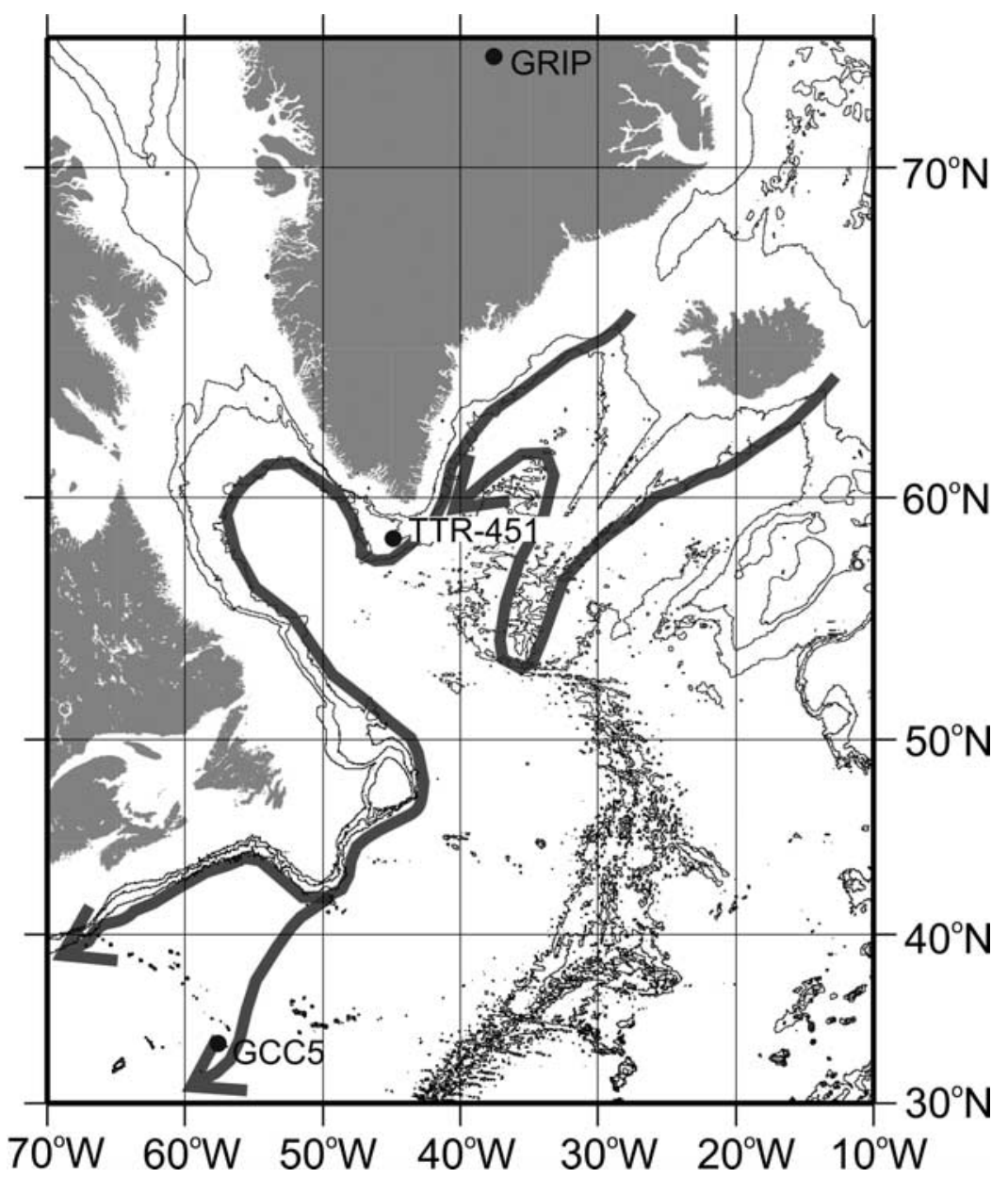

Figure 1. Location of core TTR-451. Also shown are the locations of marine core GGC5 and the Greenland Ice Core Project (GRIP) ice core drill site. The dark grey arrows indicate the North Atlantic Deep Water (NADW) flow path [after Schmitz and McCartney, 1993].

ciated with meltwater injections, we present a new highresolution record of NADW flow intensity during the last deglaciation, as recorded in core TTR13-AT451G (hereinafter referred to as TTR-451) from Eirik Drift (south of Greenland) (Figure 1). The results are then placed within the context of recent suggestions about the location and depth-distribution of meltwater pulses [Aharon, 2005; Tarasov and Peltier, 2005]. Modern observations of surface freshening and sea ice reductions in the Arctic Ocean and Nordic Seas [Dickson et al., 2002; Lindsay and Zhang, 2005] and reduced formation of NADW [Dickson et al., 2002; Bryden et al., 2005] underline the need for a better understanding of the potential ocean-climate responses to meltwater injections.

\section{Revised Ages of mwp-1a and Greenland Climate Events}

[5] The fossil reef series indicates a sharp global sea level rise of about $20 \mathrm{~m}$ at around $14 \mathrm{ka}$ (Figure $2 \mathrm{~b}$ ): meltwater pulse 1a (mwp-1a) [Fairbanks, 1990]. Gaussian smoothing through the recently improved data series for Barbados
[Fairbanks et al., 2005; Peltier and Fairbanks, 2006] illustrates the history of sea level change through time (Figure $2 b$ ), and its first time derivative offers insight into rates of sea level change (Figure 2c). The latter clearly identifies mwp-1a between 14.17 and $13.61 \mathrm{ka}$, with a peak rate of $4.3 \mathrm{~cm} \mathrm{yr}^{-1}$ sea level rise close to $13.86 \mathrm{ka}$. The youngest indicator of low pre-mwp-1a sea level is sample RGF 9-8-2, which was originally U/Th-dated at $14.235 \pm$ $0.050 \mathrm{ka}(1 \sigma)$ [Bard et al., 1990a, 1990b] and was recently re-dated at $14.082 \pm 0.028 \mathrm{ka}(1 \sigma)$ using higher precision mass spectrometry and new decay constants [Fairbanks et al., 2005]. This single young point has been questioned [Kienast et al., 2003; Weaver et al., 2003] since Sunda shelf data suggest that mwp-1a started considerably earlier, at around $14.6 \mathrm{ka}$ [Hanebuth et al., 2000]. However, the Sunda shelf record relies upon $\mathrm{AMS}^{14} \mathrm{C}$ ages, which are subject to much greater uncertainty than $\mathrm{U} / \mathrm{Th}$ chronologies, especially when corrections for variable ${ }^{14} \mathrm{C}$ reservoir ages are considered. Recent improvements in the resolution of the Barbados record have added six new low (pre-mwp-1a) sea level points between 14.60 and $14.08 \mathrm{ka}$ that comprehensively validate the age of sample RGF 9-8-2 (Table 1, 


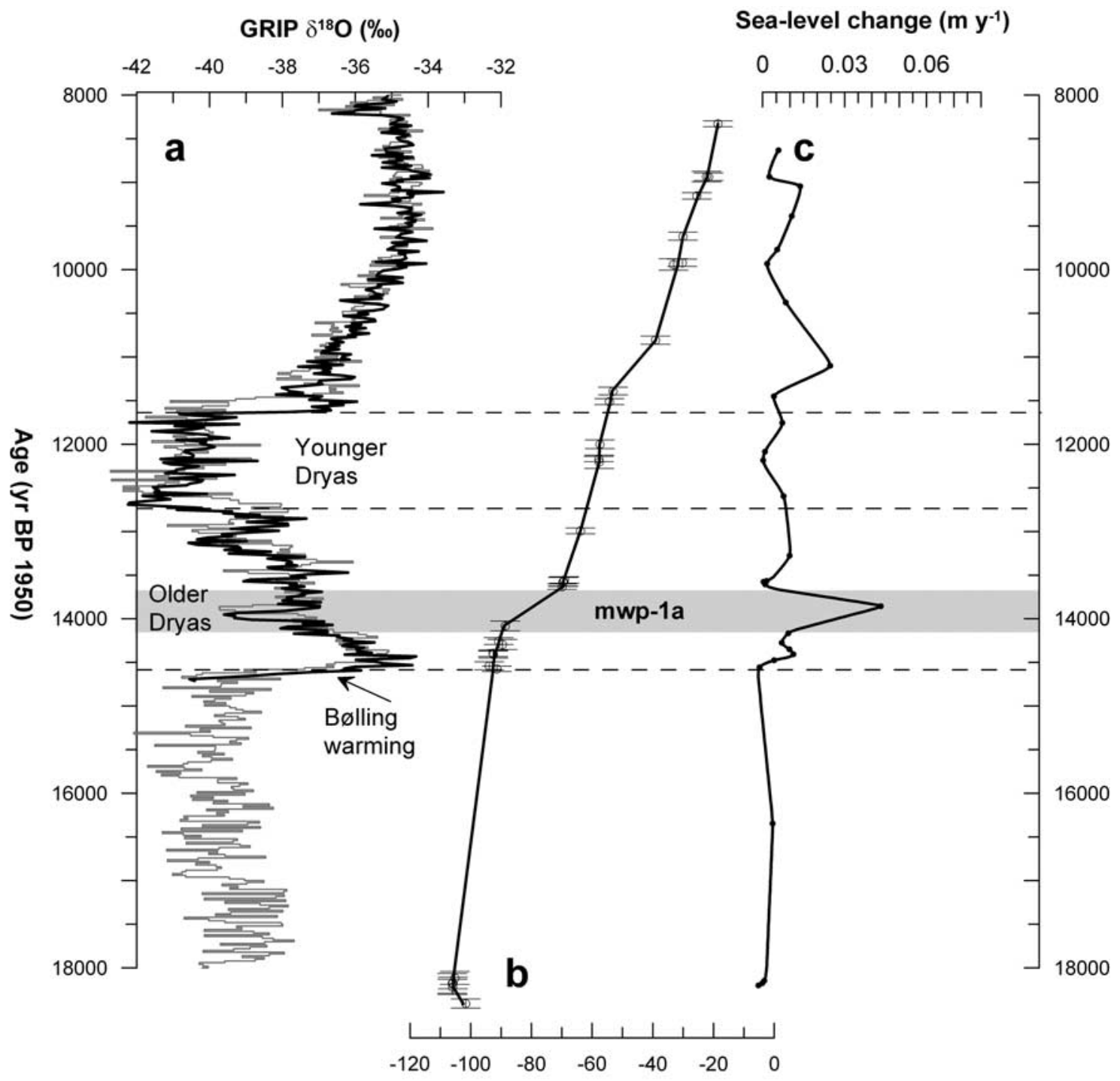

\section{Sea-level ( $\mathrm{m}$ below present)}

Figure 2. (a) The GRIP ice core $\delta^{18} \mathrm{O}$ record. The thin grey line is the record plotted versus the previous (modeled) ss09sea timescale [Johnsen et al., 2001]. The heavy black line is plotted versus the new GICC05 timescale on the basis of layer-counting down to $14.73 \mathrm{ka}$ [Rasmussen et al., 2006]. (b) The sea level record based on U/Th-dated corals from Barbados [Fairbanks et al., 2005; Peltier and Fairbanks, 2006] (see also Table 1). Error bars indicate $2 \sigma$ limits. (c) Record of rate of sea level change, determined as the first time derivative of the solid line in Figure $2 b$.

see also Auxiliary Materials ${ }^{1}$ ) [Fairbanks et al., 2005; Peltier and Fairbanks, 2006].

[6] Stable oxygen isotope ratios $\left(\delta^{18} \mathrm{O}\right)$ of ice from Greenland ice cores reflect temperature and air mass variations over the ice sheet. More negative values generally represent colder conditions, and less negative values represent warmer conditions. Recent layer-counting has provided a common timescale for three key ice cores from the Greenland ice sheet back to $14.73 \mathrm{ka}$ (DYE-3, Greenland Ice Core Project (GRIP), and NorthGRIP) [Rasmussen et al., 2006; Vinther et

\footnotetext{
${ }^{1}$ Auxiliary materials are available in the HTML. doi:10.1029/ 2006PA001340.
}

al., 2006]. The resultant new GICC05 timescale is in good overall agreement with that of the fourth key record from the Greenland ice sheet (GISP2) [Meese et al., 1997]. In the GRIP ice core $\delta^{18} \mathrm{O}$ record, a sharp shift near the bottom of the layer-counted series (Figure 2a, black) marks the abrupt onset of the Bølling (GI-1e) [Björck et al., 1998] warm period. In the GICC05 timescale this warming is dated at $14.64 \mathrm{ka}$, with a maximum error of 186 years [Rasmussen et al., 2006], which is in close agreement with its layercounted age of $14.65 \pm 0.09 \mathrm{ka}$ in Cariaco Basin [Lea et al., 2003]. These tight constraints place the warming some 60 years earlier than the previous, less certain, ss09sea ice core timescale [Johnsen et al., 2001] (Figure 2a, thin grey). 
Table 1. U/Th and ${ }^{14} \mathrm{C}$ Ages of the Samples Identifying Meltwater Pulse 1a in the Barbados Coral Record ${ }^{\mathrm{a}}$

\begin{tabular}{|c|c|c|c|c|c|c|c|c|}
\hline Sample Code & Species & RSL, m & Mean U/Th Age, years B.P. & $2 \sigma$, years & $\mathrm{N}$ & Mean ${ }^{14} \mathrm{C}$ Age, years B.P. & $2 \sigma$, years & $\mathrm{N}$ \\
\hline RGF 12-9-5 & A. palmata & -57.59 & 12,203 & 76 & 1 & 10,485 & 70 & 1 \\
\hline RGF $12-15-4$ & A. palmata & -63.78 & 12,993 & 34 & 2 & 11,464 & 78 & 4 \\
\hline RGF $12-21-2$ & A. palmata & -69.06 & 13,555 & 38 & 1 & 11,903 & 56 & 2 \\
\hline RGF 12-21-6 & A. palmata & -69.35 & 13,574 & 52 & 1 & 11,945 & 70 & 1 \\
\hline RGF 12-21-7 & A. palmata & -69.57 & 13,578 & 52 & 1 & 11,909 & 88 & 4 \\
\hline RGF $12-21-10$ & A. palmata & -69.85 & 13,632 & 32 & 1 & 12,075 & 60 & 1 \\
\hline RGF 9-8-2 & A. palmata & -88.60 & 14,082 & 56 & 2 & 12,615 & 80 & 1 \\
\hline RGF 9-11-2 & A. palmata & -90.75 & 14,255 & 40 & 3 & 12,735 & 80 & 1 \\
\hline RGF 9-9-7 & A. palmata & -89.51 & 14,295 & 58 & 1 & 12,795 & 80 & 1 \\
\hline RGF 9-12-7 & A. palmata & -92.57 & 14,396 & 36 & 2 & 12,780 & 50 & 2 \\
\hline RGF 9-12-5 & A. palmata & -92.49 & 14,408 & 40 & 1 & 12,780 & 80 & 2 \\
\hline RGF $15-5-3$ & A. palmata & -91.34 & 14,573 & 30 & 1 & 12,730 & 70 & 1 \\
\hline RGF 9-13-3 & A. palmata & -93.89 & 14,539 & 46 & 1 & 12,680 & 60 & 1 \\
\hline RGF 9-21-11 & A. palmata & -106.09 & 18,176 & 112 & 1 & 15,405 & 60 & 1 \\
\hline
\end{tabular}

${ }^{\mathrm{a}}$ Radiocarbon ages are reported without reservoir age subtraction. Ages are after Fairbanks et al. [2005]. All reported ${ }^{14} \mathrm{C}$ ages are conventional ${ }^{14} \mathrm{C}$ ages before 1950 (5568 year half-life, corrected for fractionation). Errors are given at the $2 \sigma$ level for both ${ }^{14} \mathrm{C}$ and ${ }^{230} \mathrm{Th}$ ages. All ${ }^{230} \mathrm{Th}$ ages are expressed as years before 1950. The relative sea levels (RSL) are the depth of Acropora palmata recovery corrected for a constant uplift of $0.34 \mathrm{~m} / \mathrm{kyr}\left({ }^{230} \mathrm{Th}\right.$ ages are used for the uplift correction). Mwp-1a is bracketed in Barbados between samples from cores 9 and 12 .

Note that the total uncertainty of the GICC05 timescale, which amounts to only 186 years at around the Bølling warm transition, mainly consists of the maximum counting error (related to the number of annual layers that were difficult to interpret) and a possible bias (because the rules used for identifying annual layers cannot be independently validated). Comparison of the GICC05 timescale with the INTCAL04 radiocarbon calibration curve based on volcanic horizons [Rasmussen et al., 2006] indicates that the maximum counting error in GICC05 is a conservative and adequate measure of the total uncertainty of the GICC05 timescale in this interval.

[7] For the first time, the age models of both ice cores and sea level evolution are constrained with sufficient accuracy to permit sensible comparisons. If the 186-year uncertainty in the GICC05 age of 14.64 ka for the Bølling onset were entirely systematically biased toward the younger bound, then its youngest possible age would be $14.45 \mathrm{ka}$. Note that it is unlikely that the errors in the GICC05 timescale are distributed in such a systematic manner, especially given the excellent agreement with ages from Cariaco Basin [Lea et al., 2003]. On the basis of RGF 9-8-2, the maximum age for the onset of mwp-1a would be $14.11(1 \sigma)$ or $14.14 \mathrm{ka}(2 \sigma)$. Hence mwp-1a apparently lags the Bølling onset by 5 to 6 centuries. Even when pushing the edges of the confidence limits in the two timeframes, mwp-1a lags the Bølling onset by 3 centuries. This firmly corroborates the age offset suggested independently by radiocarbon results, which by themselves are insufficiently precise to be conclusive owing to reservoir age uncertainties (see Auxiliary Materials). Consequently, there is no longer a reasonable case to assume that mwp-1a coincided with the Bølling onset. We therefore reject the hypothesis that mwp-1a may have triggered the abrupt onset of the Bølling warm period [Kienast et al., 2003; Weaver et al., 2003].

[8] The new time constraints instead confirm a previous suggestion [Bard et al., 1996] that mwp-1a was associated with the termination of the Bølling warm period (Figures 2a-2c). Meltwater addition started within the Bølling, possibly as a direct response to high-latitude warming during that period [McManus et al., 2004], and culminated in a meltwater peak at 13.9 ka that coincides with the sharp "Older Dryas" (GI-1d) [Björck et al., 1998] cooling event. At issue, however, is whether there was a change in NADW flow intensity coincident with mwp-1a and the Older Dryas.

\section{Methods}

[9] Core TTR-451 was recovered from Eirik Drift in 2003 during a research cruise of R/V Professor Logachev (latitude $55^{\circ} 31^{\prime} \mathrm{N}$, longitude $44^{\circ} 54^{\prime} \mathrm{W}$, water depth $1927 \mathrm{~m}$ ) (Figure 1). As a contourite deposit formed where the combined flow of NADW from the Nordic Seas rounds the tip of southern Greenland [Chough and Hesse, 1985], Eirik Drift is a key monitoring site for NADW flow intensity. We present $\mathrm{AMS}^{14} \mathrm{C}$ datings (Table 1, Figure 3), and magnetic property measurements for core TTR-451 (Figures $3 \mathrm{~b}$ and $4 \mathrm{e}$ ), along with ice rafted debris (IRD) counts of lithic grains $(>150 \mu \mathrm{m})$ per gram of dry sediment (Figure 4d). Details of methods for each type of analysis are given below.

\subsection{Chronology of Core TTR-451}

[10] The chronology of TTR-451 is primarily constrained by seven $\mathrm{AMS}^{14} \mathrm{C}$ datings of monospecific samples of leftcoiling $N$. pachyderma that have been calibrated using Calib5.0.1 with a reservoir age correction $\Delta \mathrm{R}=0$ (Table 2). Within these constraints, the age model is finetuned using a robust correlation between the TTR-451 magnetic susceptibility $(\kappa)$ record and the GRIP ice core $\delta^{18} \mathrm{O}$ record (see correlation lines in Figure 3), similar to methods used previously [e.g., Dokken and Jansen, 1999; Kissel et al., 1999]. The fine-tuned age model remains well within the $2 \sigma$ bounds on four of the calibrated radiocarbon datings (squares in Figure 3a), just within the $2 \sigma$ bounds for one dating, and just outside the $2 \sigma$ bounds for two datings (Figure 3a). We note that the fine-tuned age model remains well within the $2 \sigma$ bounds of the calibrated $\mathrm{AMS}^{14} \mathrm{C}$ during intervals for which $\Delta \mathrm{R}$ values is generally thought to have been close to zero [Hughen et al., 2000; Bondevik et al., 2006]. Our fine-tuned age model suggests somewhat enhanced $\Delta \mathrm{R}$ values for the three radiocarbon datings from the Younger Dryas (YD) and Heinrich event 1 (H1) 


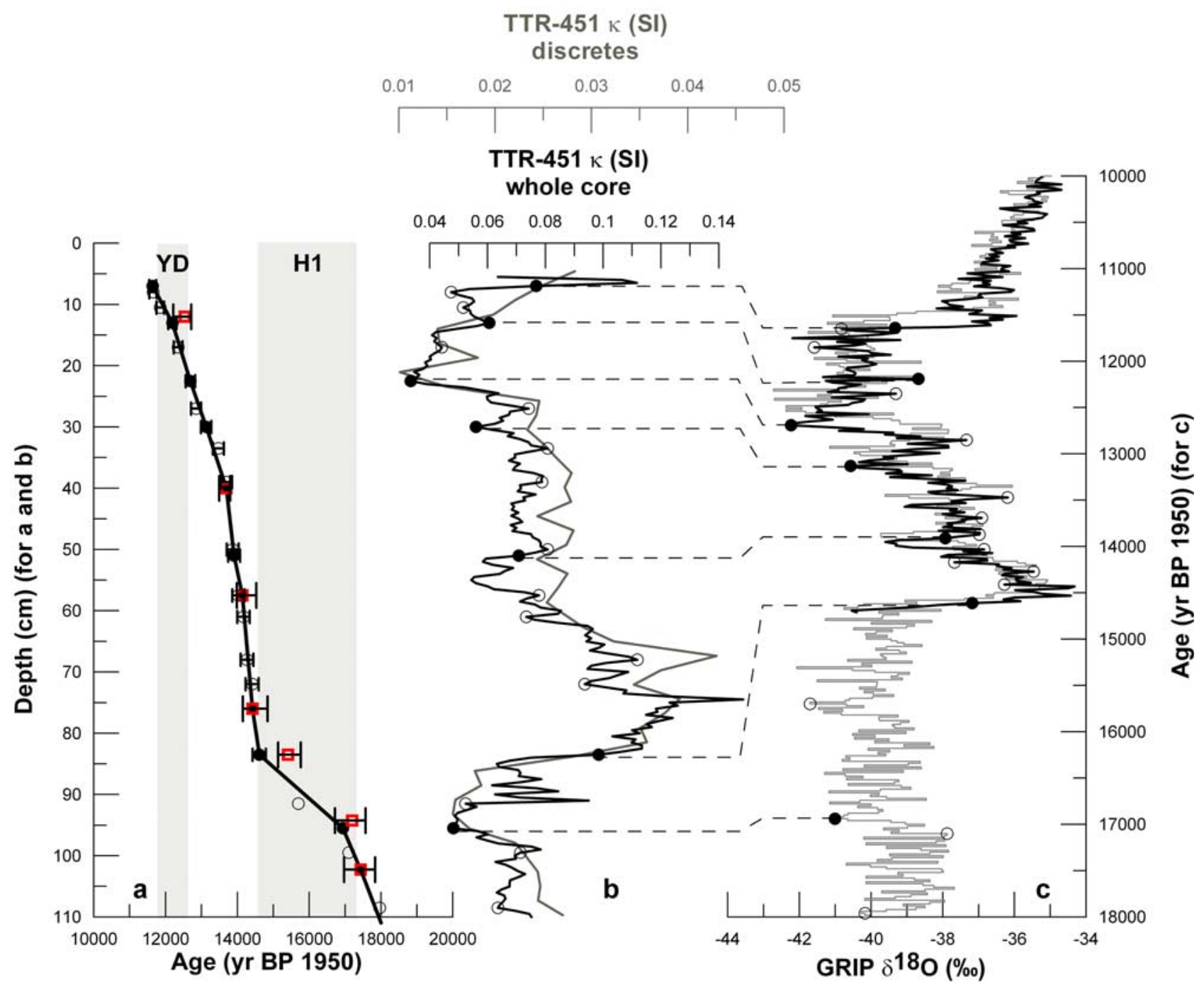

Figure 3. (a) Depth versus age plot for core TTR-451. Squares indicate calibrated $\mathrm{AMS}^{14} \mathrm{C}$ datings, and error bars indicate the $2 \sigma$ uncertainty range (Table 2). Solid black circles indicate tie points from the correlation between the magnetic susceptibility and the GRIP ice core $\delta^{18} \mathrm{O}$ record, and open black circles represent extra correlation points between the magnetic susceptibility of core TTR-451 and the GRIP ice core record that are not used to construct the age model but are shown for validation. $2 \sigma$ error bars indicate the maximum counting error on the GICC05 timescale. The grey, shaded areas represent the times of reduced NADW ventilation associated with the Younger Dryas and Heinrich event 1 [McManus et al., 2004]. (b) The magnetic susceptibility records for TTR-451: black denotes the higher-resolution whole core data, and grey denotes the lower-resolution discrete sample measurements. (c) The GRIP ice core $\delta^{18} \mathrm{O}$ record. The thin grey line is the record plotted on the ss09sea timescale [Johnsen et al., 2001], whereas the black line is plotted versus the new GICC05 timescale based on layer-counting down to $14.73 \mathrm{ka}$ [Rasmussen et al., 2006]. YD is Younger Dryas; H1 is Heinrich event 1.

intervals (Figure 3a), again in agreement with previous suggestions that ${ }^{14} \mathrm{C}$ reservoir ages were substantially increased during those times [Hughen et al., 2000, 2004; Bondevik et al., 2006]. We approximate $\Delta \mathrm{R}$ for those datings using the difference between the ages derived from the magnetic susceptibility tie points (absolute calendar ages) and the calibrated $\mathrm{AMS}^{14} \mathrm{C}$ datings (Table 2). The inferred $\Delta R$ value for the Younger Dryas $(\Delta R=437$ years, Table 2) compares well (just within $1 \sigma$ ) with independently derived $\Delta \mathrm{R}$ estimates of 371 years, based on cores from the Norwegian margin [Bondevik et al., 2006].

\subsection{IRD Counts}

[11] Dried samples were weighed, wet sieved $(>63 \mu \mathrm{m})$, and oven dried. The dried sand fraction was dry sieved and each fraction weighed. Suitable aliquots of the coarse $(>150 \mu \mathrm{m})$ fraction were weighed and the particles counted under a binocular microscope. On average, $\sim 500$ grains were counted per sample, and the grain types distinguished. The IRD counts are shown in Figure 4d, and a distinct $\sim 500$ year IRD minimum reflects the Bølling warm period, lending further support to our age model for core TTR-451. 


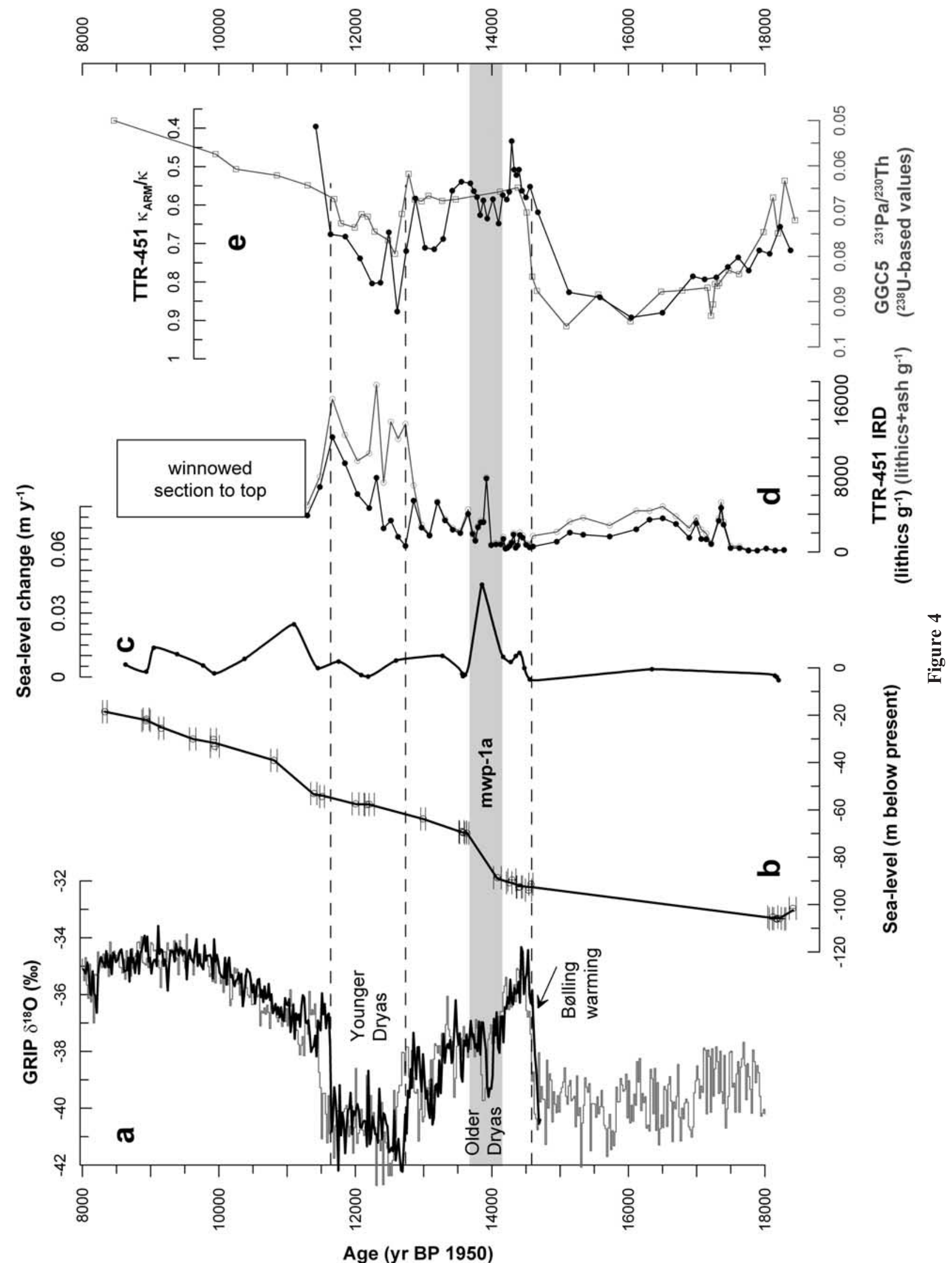


Table 2. $\mathrm{AMS}^{14} \mathrm{C}$ Measurements for Core TTR- $451^{\mathrm{a}}$

\begin{tabular}{|c|c|c|c|c|c|c|}
\hline Depth, cm & Species & $\begin{array}{c}\text { Radiocarbon } \\
\text { Conventional Age } \\
\end{array}$ & $\begin{array}{l}\text { Calibrated Age } \\
\text { (calib 5.0.1.) }\end{array}$ & $2 \sigma$ Age Range & Inferred $\Delta \mathrm{R}$ & $2 \sigma$ Range for the $\Delta \mathrm{R}$ \\
\hline 12.00 & N. pachyderma (lc) & $10,905 \pm 60$ B.P. & 12,535 B.P. & $12,213-12,715$ & 437 & $96-650$ \\
\hline 40.00 & N. pachyderma (lc) & $12,220 \pm 55$ B.P. & 13,692 B.P. & $13,495-13,800$ & & \\
\hline 57.50 & N. pachyderma (lc) & $12,690 \pm 55$ B.P. & 14,141 B.P. & $13,986-14,527$ & & \\
\hline 76.00 & N. pachyderma (lc) & $12,825 \pm 55$ B.P. & 14,420 B.P. & $14,154-14,843$ & & \\
\hline 83.50 & N. pachyderma (lc) & $13,460 \pm 55$ B.P. & 15,411 B.P. & $15,136-15,769$ & 801 & $470-1204$ \\
\hline 94.25 & N. pachyderma (1c) & $14,750 \pm 60$ B.P. & 17,196 B.P. & $16,720-17,568^{\mathrm{b}}$ & 499 & \\
\hline 102.25 & N. pachyderma (1c) & $14,890 \pm 60$ B.P. & 17,432 B.P. & $16,975-17,839$ & & \\
\hline
\end{tabular}

${ }^{a} \mathrm{AMS}^{14} \mathrm{C}$ measurements measured from monospecific samples of $N$. pachyderma, left coiling (lc), and their calibrated (calendar) ages for core TTR-451. Inferred $\Delta \mathrm{R}$ values are also presented for $\mathrm{AMS}^{14} \mathrm{C}$ datings that represent the Younger Dryas and Heinrich event 1.

${ }^{\mathrm{b}}$ The $2 \sigma$ errors for the ages of the GRIP $\delta^{18} \mathrm{O}$ ice core record on the ss09sea timescale are not constrained [Johnsen et al., 2001] but are considered larger than those for the GICC05 timescale (186 years at the Bølling transition).

\subsection{Magnetic Measurements}

[12] The ratio of susceptibility of the anhysteretic remanent magnetization $\left(\kappa_{\mathrm{ARM}}\right)$ to low-field magnetic susceptibility $(\kappa)$ for core TTR-451 is shown in Figure 4e. These data were obtained from discrete samples that have been cross-validated by comparison with additional u-channel $\kappa_{\mathrm{ARM}}$ measurements (not shown) and the higher-resolution whole core magnetic susceptibility record (Figure 3b). The whole core magnetic susceptibility was measured with a Bartington Instruments MS2E1 point sensor that was placed in contact with the surface of a split core (labeled as "whole core" in Figure $3 b$ ). The discrete sample magnetic susceptibility measurements were made using a Kappabridge KLY-4 magnetic susceptibility meter, and $\kappa_{\text {ARM }}$ was imparted using a $50 \mu \mathrm{T}$ bias field and an alternating field of $100 \mathrm{mT}$, with measurements made using a 2G-Enterprise cryogenic magnetometer.

\section{Results}

[13] Previous studies have invoked a relationship between large meltwater pulses into the Atlantic Ocean and coincident cooling over large parts of the Northern Hemisphere, through reduction of deepwater formation in the Nordic Seas and the associated oceanic poleward heat transport [e.g., Broecker, 1991; Rahmstorf, 1995]. Our new proxy record for the strength of NADW overflow from Eirik Drift (Figure 4e) allows us to test the hypothesis that mwp-1a may have caused the termination of the Bølling warm period.

[14] The $\kappa_{\mathrm{ARM}} / \kappa$ ratio is a proxy for magnetic mineral grain size when sediments are magnetically dominated by (titano)magnetite [Banerjee et al., 1981; Verosub and Roberts, 1995]. Previous work supports the assumption of constant magnetic mineralogy along the NADW flow path in the vicinity of Eirik Drift [Kissel et al., 1999; Laj et al.,
2002]. Eirik Drift represents a key region for deposition of suspended matter transported out of the Nordic Seas, especially for transportation via deepwater overflow through Denmark Strait (between Iceland and Greenland). The magnetic mineral content of sediments in that region originates from a single common source (the Nordic basaltic province) [Kissel et al., 1999; Laj et al., 2002]. Our new $\kappa_{\mathrm{ARM}} / \kappa$ record from Eirik Drift therefore reflects variations in the size of the coarsest magnetic grains that can be carried by NADW out of the Nordic Seas and that settle out on Eirik Drift as NADW rounds the southern tip of Greenland. Lower $\kappa_{\mathrm{ARM}} / \kappa$ values represent coarser grain sizes [Banerjee et al., 1981], and therefore increased intensity of NADW formation (Figure 4e; note the inverted scale).

[15] Our $\kappa_{\mathrm{ARM}} / \kappa$ record for core TTR-451 is shown in Figure $4 \mathrm{e}$, along with another (independently dated) record of NADW flow rate, which is based on the ${ }^{231} \mathrm{~Pa} /{ }^{230} \mathrm{Th}$ ratio in core GGC5 from Bermuda Rise [McManus et al., 2004]. The suggestion that magnetic mineral concentration and grain size reflect changes in NADW flow strength [Kissel et al., 1999; Laj et al., 2002] is empirically corroborated by the high degree of structural similarity between our $\kappa_{\text {ARM }} / \kappa$ record and the ${ }^{231} \mathrm{~Pa}^{230} \mathrm{Th}$ record from core GGC5 (Figure 4e). Note that the apparent offset at the Bølling transition results only from sample resolution (this is verified by a sharper shift in our higher-resolution, "whole core" measurements (not shown) that agrees closely with the ${ }^{231} \mathrm{~Pa} /{ }^{230} \mathrm{Th}$ shift at that time). Compared to the ${ }^{231} \mathrm{~Pa}{ }^{230} \mathrm{Th}$ record, our $\kappa_{\mathrm{ARM}} / \kappa$ record offers a higher temporal resolution between the onset of the Bølling and the onset of the Younger Dryas (Figure 4e). A distinct NADW slowdown is suggested during the cooling from about 14.2 ka that culminated in the Older Dryas at around $14.0 \mathrm{ka}$. This suggests that the Bølling warm period may have been terminated by a reduction in deepwater formation

Figure 4. (a) The GRIP ice core $\delta^{18} \mathrm{O}$ record. The thin grey line is the record plotted versus the previous (modeled) ss09sea timescale [Johnsen et al., 2001]. The heavy black line is plotted versus the new GICC05 timescale based on layercounting down to $14.73 \mathrm{ka}$ [Rasmussen et al., 2006]. (b) The sea level record based on U/Th-dated corals from Barbados [Fairbanks et al., 2005; Peltier and Fairbanks, 2006] (see also Table 1). Error bars indicate $2 \sigma$ limits. (c) Record of rate of sea level change, determined as the first time derivative of the solid line in Figure 4b. (d) Counts of lithic fragments, larger than $150 \mu \mathrm{m}$, per gram of dry sediment weight in Eirik Drift core TTR-451. Black indicates lithic grains excluding volcanic glass, and grey indicates lithic grains including volcanic glass. The Holocene is represented in core TTR-451 by an intensely winnowed (sand) layer, suggesting a strong bottom-current regime. (e) Record of $\kappa_{\mathrm{ARM}} / \kappa$ for Eirik Drift core TTR-451 from discrete samples (in black). The $\kappa_{\mathrm{ARM}} / \kappa$ data for TTR-451 are presented alongside the ${ }^{231} \mathrm{~Pa} /{ }^{230} \mathrm{Th}$ record of core GGC05 from Bermuda Rise (in grey) [McManus et al., 2004]. 
in the Nordic Seas, and consequently reduced oceanic poleward heat transport, coincident with mwp-1a.

\section{Discussion and Wider Implications}

[16] Our compilation of records demonstrates that direct climate impacts are not proportional to either the magnitude, or the rate, of meltwater addition (compare Figure 4a with Figures $4 \mathrm{~b}$ and $4 \mathrm{c}$ ), and neither is the NADW flow intensity (compare Figure $4 \mathrm{e}$ with Figures $4 \mathrm{~b}$ and $4 \mathrm{c}$ ). First, the dramatic mwp-1a event is found to be associated with only a slowdown (not shutdown) of NADW flow, and only a brief (100-150 years) direct climatic anomaly. Second, the widespread and long-lasting Younger Dryas cold reversal (Figure 4a) clearly lacks a discernible meltwater pulse (Figures $4 \mathrm{~b}$ and $4 \mathrm{c}$ ), but it was characterized by significant NADW slowdown (not shutdown) (Figure 4e). Third, there is little evidence [Hanebuth et al., 2000] for rapid sea level rise/meltwater addition during the $2-3 \mathrm{kyr}$ interval centered on 16 ka ("Heinrich event 1" [Hemming, 2004; McManus et al., 2004]), but this major cold period was marked by near NADW shutdown [McManus et al., 2004] (Figure 4e).

[17] Nonlinear responses of ocean circulation to the magnitude and rate of meltwater additions may be expected in a system with different quasi-stable climate states and abrupt meltwater-driven transitions [Rahmstorf, 1995; Ditlevsen, 1999]. However, it has also been argued that the location and nature of meltwater entry may be more important for NADW formation than the magnitude or rate [Moore, 2005; Tarasov and Peltier, 2005]; smaller surface-bound additions in critical locations could outweigh large additions elsewhere and over greater depth ranges (hyperpycnal additions).

[18] A considerable component of meltwater associated with mwp-1a is thought to have entered the ocean via the Gulf of Mexico [Flower et al., 2004], in a hyperpycnal manner [Aharon, 2005], and strong mixing with seawater would have reduced its impact on NADW formation [Tarasov and Peltier, 2005; Aharon, 2005]. Conversely, surface (iceberg) meltwater injection from Hudson Strait during Heinrich event 1, although not dramatically evident in the sea level record [Fairbanks, 1989; Aharon, 2005; Peltier and Fairbanks, 2006] (Figures 4b and 4c), may have sufficiently affected the Nordic Seas to cause a collapse of NADW formation (Figure 4e). The pronounced Younger Dryas event, associated with severely reduced NADW formation (Figure 4e), has also been ascribed to a surface (iceberg) meltwater flux, that was small enough to remain undetectable in terms of sea level, into this critical region (from the Arctic [Moore, 2005; Tarasov and Peltier, 2005]). A meltwater signal into that region has been detected on the SE Greenland shelf [Jennings et al., 2006].

[19] The combined results presented here demonstrate that NADW formation and its associated climatic impacts are not simply governed by the magnitude and/or rate of meltwater addition. If indeed the climate forcing was dependent on freshwater input, then (small) freshwater additions targeted on the Arctic/Nordic Seas appear to carry a much greater risk of disrupting NADW formation. Alternatively, it should be considered that the inferred nonlinear responses of ocean circulation to the magnitude and rate of meltwater additions indicate that meltwater input was not necessarily the primary driver. To evaluate this, new records are required that constrain other potential aspects of the ocean-climate interaction, such as sea ice feedbacks [Li et al., 2005; Wunsch, 2006].

\section{Conclusions}

[20] Comparison of the GRIP ice core $\delta^{18} \mathrm{O}$ record on the new layer-counted GICC05 timescale with the better constrained U/Th-dated sea level record conclusively demonstrates that mwp-1a coincided with the Older Dryas and not the Bølling warming. By combining a new proxy record of NADW flow intensity from Eirik Drift with the Barbados sea level and Greenland ice core $\delta^{18} \mathrm{O}$ records, we show that at the time of mwp-1a and the Older Dryas, there was a brief reduction (not a shutdown) in NADW flow intensity. However, our combination of proxy records also demonstrates that more extreme cooling events (Heinrich event 1 and the Younger Dryas), which were not associated with meltwater pulses large enough to significantly affect the sea level record, were characterized by nearly collapsed NADW formation. This suggests either that there is a fundamental nonlinearity between the rate and magnitude of meltwater injection and the rate of NADW formation, with perhaps a greater importance of the location and depth-distribution of meltwater injection, or that the primary mechanism for some climate transitions lies elsewhere in the oceanclimate-atmosphere system (e.g., sea ice feedbacks).

[21] Acknowledgments. This study was supported by the Natural Environment Research Council as part of the RAPID and QUEST programmes. We acknowledge the crew and scientists onboard R/V Professor Logachev, BOSCORF, and Leibniz Labor, Kiel, for the $\mathrm{AMS}^{14} \mathrm{C}$ datings. We would also like to thank the referees who helped to improve our manuscript. R. G. Fairbanks' sea level and radiometric dating programs were supported by U.S. NSF grants ATM03-27722 and OCE99-11637. This is LDEO contribution number 6965.

\section{References}

Aharon, P. (2005), Entrainment of meltwaters in hyperpycnal flows during deglaciation superfloods in the Gulf of Mexico, Earth Planet. Sci. Lett., 241, 260-270.

Banerjee, S. K., J. W. King, and J. Marvin (1981), A rapid method for magnetic granulometry with applications to environmental studies, Geophys. Res. Lett., 8, 333-336.

Bard, E., B. Hamelin, R. G. Fairbanks, and A. Zindler (1990a), Calibration of the ${ }^{14} \mathrm{C}$ timescale over the past 30,000 years using mass spectrometric U-Th ages from Barbados corals, Nature, 345, 405-410.

Bard, E., B. Hamelin, and R. G. Fairbanks (1990b), U/Th ages obtained by mass spectrometry in corals from Barbados: Sea level during the past 130,000 years, Nature, 346 , 456-458.

Bard, E., B. Hamelin, M. Arnold, L. Montaggioni, G. Cabioch, G. Faure, and F. Rougerie (1996),
Sea level record from Tahiti corals and the timing of deglacial meltwater discharge, Nature, 382, 241-244.

Bard, E., M. Arnold, B. Hamelin, N. TisneratLaborde, and G. Cabioch (1998), Radiocarbon calibration by means of mass spectrometric ${ }^{230} \mathrm{Th} /{ }^{234} \mathrm{U}$ and ${ }^{14} \mathrm{C}$ ages of corals: An updated data base including samples from Barbados, Mururoa and Tahiti, Radiocarbon, 40, 1085-1092. 
Björck, S., et al. (1998), An event stratigraphy for the Last Termination in the North Atlantic region based on the Greenland ice-core record: A proposal by the INTIMATE group, $J$. Quat. Sci., 13, 283-292.

Bondevik, S., J. Mangerud, H. H. Birks, S. Gulliksen, and P. Reimer (2006), Changes in North Atlantic radiocarbon reservoir ages during the Allerød and Younger Dryas, Science, 312, 1514-1517.

Broecker, W. S. (1991), The great ocean conveyor, Oceanography, 4, 79-89.

Bryden, H. L., H. R. Longworth, and S. Cunningham (2005), Slowing of the Atlantic meridional overturning circulation at $25^{\circ} \mathrm{N}$, Nature, 438, 655-657.

Chough, S. K., and R. Hesse (1985), Contourites from Eirik Ridge, south of Greenland, Sediment. Geol., 41, 185-199.

Clark, P. U., R. B. Alley, L. D. Keigwin, J. M. Licciardi, S. J. Johnsen, and H. Wang (1996), Origin of the first global meltwater pulse following the last glacial maximum, Paleoceanography, 11, 563-577.

Clark, P. U., J. X. Mitrovica, G. A. Milne, and M. E. Tamisiea (2002), Sea-level fingerprinting as a direct test for the source of global meltwater pulse 1a, Science, 295, $2438-$ 2441.

Dickson, B., I. Yashayaev, J. Meincke, B. Turrell, S. Dye, and J. Holfort (2002), Rapid freshening of the deep North Atlantic Ocean over the past four decades, Nature, 416, 832-837.

Ditlevsen, P. D. (1999), Observation of $\alpha$-stable noise induced millennial climate changes from an ice-core record, Geophys. Res. Lett., 26, $1441-1444$.

Dokken, T. M. J., and E. Jansen (1999), Rapid change in the mechanism of ocean convection during the last glacial period, Nature, 401, $458-461$

Fairbanks, R. G. (1989), A 17,000-year glacioeustatic sea level record: Influence of glacial melting rates on the Younger Dryas event and deep-ocean circulation, Nature, $342,637-642$.

Fairbanks, R. G. (1990), The age and origin of the Younger Dryas climate event in Greenland ice cores, Paleoceanography, 5, 937-948.

Fairbanks, R. G., R. A. Mortlock, T.-C. Chiu, L. Cao, A. Kaplan, T. P. Guilderson, T. W. Fairbanks, A. L. Bloom, P. M. Grootes, and M.-J. Nadeau (2005), Radiocarbon calibration curve spanning 0 to 50,000 years BP based on paired ${ }^{230} \mathrm{Th} /{ }^{234} \mathrm{U} /{ }^{238} \mathrm{U}$ and ${ }^{14} \mathrm{C}$ dates on pristine corals, Quat. Sci. Rev., 24, 1781-1796.

Flower, B. P., D. W. Hastings, H. W. Hill, and T. M. Quinn (2004), Phasing of deglacial warming and Laurentide Ice Sheet meltwater in the Gulf of Mexico, Geology, 32, 597-600.

Hanebuth, T., K. Stattegger, and P. M. Grootes (2000), Rapid flooding of the Sunda shelf: A late-glacial sea-level record, Science, 288, $1033-1035$

Hemming, S. R. (2004), Heinrich Events: Massive late Pleistocene detritus layers of the North Atlantic and their global imprint, Rev. Geophys., 42, RG1005, doi10.1029/ 2003RG000128.
Hughen, K. A., J. Southon, S. J. Lehman, and J. Overpeck (2000), Synchronous radiocarbon and climate shifts during the last deglaciation, Science, 290, 1951-1954.

Hughen, K. A., S. J. Lehman, J. Southon J. Overpeck, O. Marchel, C. Herring, and J. Turnbull (2004), ${ }^{14} \mathrm{C}$ activity and global carbon cycle changes over the past 50,000 years, Science, 303, 202-207.

Jennings, A. E., M. Hald, M. Smith, and J. T. Andrews (2006), Freshwater forcing from the Greenland Ice Sheet during the Younger Dryas: Evidence from southeastern Greenland shelf cores, Quat. Sci. Rev., 25, 282-298.

Johnsen, S. J., D. Dahl-Jensen, N. Gundestrup, J. P. Steffensen, H. B. Clausen, H. Miller, V. Masson-Delmotte, A. E. Sveinbjörndottir and A. J. White (2001), Oxygen isotope and palaeotemperature records from six Greenland ice-core stations: Camp Century, Dye-3, GRIP, GISP2, Renland and NorthGRIP, J. Quat. Sci., 16, 299-307.

Kienast, M., T. J. J. Hanebuth, C. Pelejero, and S. Steinke (2003), Synchroneity of meltwater pulse 1a and the Bølling warming: New evidence from the South China Sea, Geology, 31 , $67-70$

Kissel, C., C. Laj, L. Labeyrie, T. Dokken, A. Voelker, and D. Blamart (1999), Rapid climatic variations during marine isotopic stage 3: Magnetic analysis of sediments from Nordic Seas and North Atlantic, Earth Planet. Sci. Lett., 171, 489-502.

Laj, C., C. Kissel, A. Mazaud, E. Michel, R. Muscheler, and J. Beer (2002), Geomagnetic field intensity, North Atlantic Deep Water circulation and atmospheric $\Delta^{14} \mathrm{C}$ during the last $50 \mathrm{kyr}$, Earth Planet. Sci. Lett., 200 , $177-190$.

Lea, D. W., D. K. Pak, L. C. Peterson, and K. A. Hughen (2003), Synchroneity of tropical and high-latitude Atlantic temperatures over the last glacial termination, Science, 301 , $1361-1364$

Li, C., D. S. Battisti, D. P. Schrag, and E. Tziperman (2005), Abrupt climate shifts in Greenland due to displacements of the sea ice edge, Geophys. Res. Lett., 32, L19702, doi:10.1029/2005GL023492.

Lindsay, R. W., and J. Zhang (2005), The thinning of Arctic sea ice, 1988-2003: Have we passed a tipping point?, J. Clim., 18, 4879-4894.

McManus, J. F., R. Francois, J.-M. Gherardi, L. D. Keigwin, and S. Brown-Leger (2004), Collapse and rapid resumption of Atlantic meridional circulation linked to deglacial climate changes, Nature, 428, 834-837.

Meese, D. A., A. J. Gow, R. B. Alley, G. A Zielinski, P. M. Grootes, M. Ram, K. C. Taylor, P. Mayewski, and J. F. Bolzan (1997), The Greenland Ice Sheet Project 2 depth-age scale: Methods and results, J. Geophys. Res. $102,26,411-26,423$

Moore, T. C., Jr. (2005), The Younger Dryas: From whence the fresh water?, Paleoceanography, 20, PA4021, doi:10.1029/ 2005PA001170.

Peltier, W. R., and R. G. Fairbanks (2006), Global ice volume and Last Glacial Maximum duration from an extended Barbados sea-level record, Quat. Sci.Rev., doi:10.1016/ j.quascirev.2006.04.010, in press.

Rahmstorf, S. (1995), Bifurcations of the Atlantic thermohaline circulation in response to changes in the hydrological cycle, Nature, $378,145-149$.

Rasmussen, S. O., et al. (2006), A new Greenland ice core chronology for the last glacia termination, J. Geophys. Res., 111, D06102, doi:10.1029/2005JD006079.

Reimer, P. J., et al. (2004), IntCal04 terrestrial radiocarbon age calibration, $0-26$ cal kyr BP, Radiocarbon, 46, 1029-1058

Rohling, E. J., M. Fenton, F. J. Jorissen, P. Bertrand, G. Gansen, and J. P. Caulet (1998), Magnitudes of sea-level lowstands of the past 500,000 years, Nature, 394, 162-165.

Schmitz, W. J., Jr., and M. S. McCartney (1993), On the North Atlantic circulation, Rev Geophys., 31, 29-49.

Siddall, M., E. J. Rohling, A. Almogi-Labin, C. Hemleben, D. Meischner, I. Schmelzer, and D. A. Smeed (2003), Sea-level fluctuations during the last glacial cycle, Nature, $423,853-858$

Tarasov, L., and W. R. Peltier (2005), Arctic freshwater forcing of the Younger Dryas cold reversal, Nature, 435, 662-665.

Verosub, K. L., and A. P. Roberts (1995), Environmental magnetism: Past, present, and future, J. Geophys. Res., 100, 2175-2192.

Vinther, B. M., H. B. Clausen, S. J. Johnsen, S. O. Rasmussen, K. K. Andersen, S. L. Buchardt, I. K. Seierstad, M.-L. SiggaardAndersen, J. P. Steffensen, and A. M. Svensson (2006), A synchronized dating of three Greenland ice cores throughout the Holocene, J. Geophys. Res., 111, D13102, doi:10.1029/ 2005JD006921.

Weaver, A. J., O. A. Saenko, P. U. Clark, and J. X. Mitrovica (2003), Meltwater pulse 1A from Antarctica as a trigger of the BøllingAllerød warm interval, Science, 299, 17091713

Wunsch, C. (2006), Abrupt climate change: An alternative view, Quat. Res., 65, 191-203.

E. Bard, Collège de France, Centre Européen de Recherche et d'Enseignement des Géosciences de l'Environnement (CEREGE), UMR 6635, Le Trocadéro, Europole de l'Arbois BP80, 13545 Aix-en-Provence cedex 4, France.

R. G. Fairbanks, Lamont-Doherty Earth Observatory, Columbia University, Palisades, NY 10964, USA

S. E. Hunter, A. P. Roberts, E. J. Rohling, and J. D. Stanford, National Oceanography Centre, University of Southampton, European Way, Southampton SO14 3ZH, UK. (e.rohling@noc. soton.ac.uk; jstan@noc.soton.ac.uk)

J. McManus, Woods Hole Oceanographic Institution, 121 Clark Lab, MS 23, Woods Hole, MA 02543, USA.

S. O. Rasmussen, Ice and Climate Research, Niels Bohr Institute, University of Copenhagen, DK-2100 Copenhagen, Denmark. 